\title{
RELATION BETWEEN THE AFFINITY FOR CONGO RED AND THE GLYCOPROTEIN CONTENT OF SERUM IN RHEUMATOID ARTHRITIS AND RELATED DISEASES*
}

\section{BØRGE LARSEN \\ From the Rheumatic Research Laboratory, University Institute of Pathological Anatomy, Copenhagen, Denmark}

Disappearance of congo red from the serum has long been considered by many investigators to be the best and most constant indicator of amyloidosis. The congo red test, as shown by Bennhold (1923), measures the proportion of this dye which is retained in the plasma one hour after its intravenous injection. The validity of this test has been the subject of intense discussion. Disappearance of 40-100 per cent. of the dye from the serum within one hour is generally regarded as a positive test, but according to Stemmerman and Auerbach (1944) and Taran and Eckstein (1942) the test should not be considered positive unless 90-100 per cent. disappears. In an experiment of Dixon, Ramcharan, and Ropes (1955), the congo red test tended towards positivity in 114 out of 227 patients with rheumatoid arthritis. In many cases of primary amyloidosis no affinity for congo red is found (Johansson and Pfeiffer, 1954), and Aegerter and Long (1949) demonstrated a positive congo red test in four out of five cases with systemic lupus erythematosus.

These observations lead to the suggestion that the disappearance of congo red from the serum is due not only to the presence of amyloid in the tissues, but also to other factors. One such possible factor that can be studied is the binding of congo red to the serum. Since congo red does not penetrate semipermeable membranes, equilibrium analysis could not be used in the present study. The method herein devised is based on a partition analysis system. Cellulose powder, which has a great affinity for congo red, was loaded with congo red. Upon shaking this congo red loaded cellulose pow'der with a buffered serum solution, congo red is taken up by the serum. The dye-binding capacity of serum from patients with rheumatoid arthritis and

\footnotetext{
* Paper presented at the IX International Congress on Rheumatic Diseases. Toronto, in June, 1957.

Aided by grants from the Danish League against Rheumatism.
}

related diseases was compared to the serum content of glycoprotein and the results are reported below.

\section{Material and Methods}

A group of 83 sera with a positive streptococcal agglutination titration were kindly furnished by Statens Serum Institute, Copenhagen, where the streptococcai $\underset{C}{C}$ agglutination titrations (S.A.T.) were performed. The $\frac{\varsigma}{2}$ control group consisted of twenty sera with negative $\mathbb{\Phi}$ (S.A.T.), 37 sera from patients with manifest rheumatoid $\overrightarrow{0}$ arthritis, and twenty normal sera collected by $\mathrm{Dn}$ Jorgen Kryger. Other sera reported were from the University Hospital of Copenhagen.

Congo Red Suspension.-50g. cellulose powde्g (Schleicher and Schüll, No. 123, from chromatography) are suspended in $200 \mathrm{ml}$. of a 0.5 per cent. congo red 을 solution in water (Congo red: Grübler and Co.). After $\stackrel{\mathbb{Q}}{\varrho}$ stirring for 2 hours, the suspension is filtered and washed $\overrightarrow{\vec{O}}$ with water until the filtrate is colourless. The washed red powder is then suspended in $\mathrm{n} / 20$ phosphate $\mathrm{pH} 7 \cdot 4$.

Procedure.--The congo red suspension is diluted $1: 5 \overline{0}$ with water. From this diluted suspension $5 \mathrm{ml}$. are taken with a Krogh syringe during stirring, and to this $5 \mathrm{ml}$. are added 25 :l. serum with a micropipette. A dry serum solution is used as standard for every set of 3 . analyses. The test tubes with serum and congo red suspension are shaken togther with a blank for one hour at room temperature. After centrifugation, the supernatant is read against the blank in a Beckmann B. 음 spectrophotometer at $525 \mathrm{~m} \mu$. The extinction of the $D$ blank read against water should not exceed $0 \cdot 03$. Having set the congo red affinity of normal sera at 100 per cent.. $N$ the standard dry serum solution was found to be 85 per $\sigma$ cent.

Serum Albumin.-This was determined by the micro N method of Waddell (1956).

Determination of Serum Glycoproteins.-Periodic Acid-e Schiff (P.A.S.) stainable serum proteins were determined $\frac{\mathscr{D}}{\mathbb{}}$ by the method of Laurell and Skoog (1956). The $\stackrel{\mathcal{S}}{+}$ intensity of the eluted fuchsin-sulphite stain of $10 \mathrm{Ll}$. serum spots on paper strips coloured by the P.A.S. staining procedure were read at $550 \mathrm{~m}: \iota$. 
TABLE I

MEAN CONGO RED AFFINITY FOR SERUM, SERUM CONTENT OF GLYCOPROTEIN, AND SERUM P.A.S. INTENSITY

\begin{tabular}{|c|c|c|c|c|}
\hline No. of Sera & Diagnosis & $\begin{array}{l}\text { Congo Red Affinity } \\
\text { (per cent.) }\end{array}$ & $\begin{array}{l}\text { Protein-bound Hexose } \\
\text { (mg. per cent.) }\end{array}$ & P.A.S. Intensity \\
\hline $\begin{array}{l}83 \\
20 \\
35 \\
19\end{array}$ & $\begin{array}{l}\text { S.A.T. Positive } \\
\text { S.A.T. Negative } \\
\text { Rheumatoid Arthritis } \\
\text { Controls }\end{array}$ & $\begin{array}{r}83 \pm 1 \cdot 1 \\
94 \pm 2 \cdot 9 \\
80 \pm 1 \cdot 8 \\
104 \pm 3 \cdot 1\end{array}$ & $\begin{array}{l}184 \pm 4 \cdot 2 \\
161 \pm 8 \cdot 1 \\
183 \pm 5 \cdot 2 \\
114 \pm 2 \cdot 2\end{array}$ & $\begin{array}{l}195 \pm 6 \cdot 7 \dagger \\
105 \pm 9 \cdot 3 \ddagger \\
174 \pm 8 \cdot 2 \\
85 \pm 4 \cdot 2\end{array}$ \\
\hline
\end{tabular}

CORRELATION COEFFICIENTS BETWEEN CONGO RED AFFINITY AND:

\begin{tabular}{|c|c|c|c|}
\hline \multicolumn{2}{|c|}{ (a) Serum Glycoprotein } & \multicolumn{2}{|c|}{ (b) P.A.S. Intensity } \\
\hline Group & $\mathbf{r}$ & Group & $\mathbf{r}$ \\
\hline $\begin{array}{l}\text { S.A.T. Positive } \\
\text { S.A.T. Negative } \\
\text { Rheumatoid Arthritis } \\
\text { Controls }\end{array}$ & $\begin{array}{l}-0 \cdot 376^{*} \\
-0.019 \\
-0 \cdot 213 \\
-0.449\end{array}$ & $\begin{array}{l}\text { S.A.T. Positive } \\
\text { S.A.T. Negative } \\
\text { Rheumatoid Arthritis } \\
\text { Controls }\end{array}$ & $\begin{array}{l}-0 \cdot 407^{*} \\
-0 \cdot 283 \\
-0 \cdot 109 \\
-0 \cdot 244\end{array}$ \\
\hline
\end{tabular}

* Statistically significant at the 0.05 level.

Total Protein-bound Hexose.-This was determined with anthrone. Using the method of Björnesjö (1955), an accuracy of 2 per cent. is obtained for each determination. The results are expressed in $\mathrm{mg}$. proteinbound non-hexosamine hexose per $100 \mathrm{ml}$. serum.

\section{Results}

The mean values and corresponding standard errors of congo red affinity and the glycoproteins, determined both as P.A.S. stainable glycoprotein and as total protein-bound hexose, are summarized in Table I for the four groups of S.A.T. positive sera, S.A.T. negative sera, rheumatoid arthritis patients, and controls. It is demonstrated that the mean of the S.A.T. positive group is significantly lower than that of the S.A.T. negative group as regards congo red affinity, and significantly higher than that of the S.A.T. negative group as regards both serum glycoprotein and P.A.S. intensity. Comparison between the groups of sera from patients with rheumatoid arthritis and from the controls gives the same significance.

For the S.A.T. positive group there is a significant negative correlation between congo red affinity values and the corresponding serum glycoprotein values $(r=--0 \cdot 376)$ and also between the congo red affinity values and the corresponding P.A.S. values $(r=-0 \cdot 407)$. For the other three groups the correlations were not significant;indeed, for the control group, between congo red affinity and serum glycoprotein there was a positive correlation but it did not attain significance level on such small numbers.

In Fig. 1 the correlation between congo red affinity and serum glycoprotein is shown graphically for eleven S.A.T. positive and eleven S.A.T. negative sera, selected at random from the two series for illustrative purposes. Where the values expressing the congo red affinity are progressing towards values of

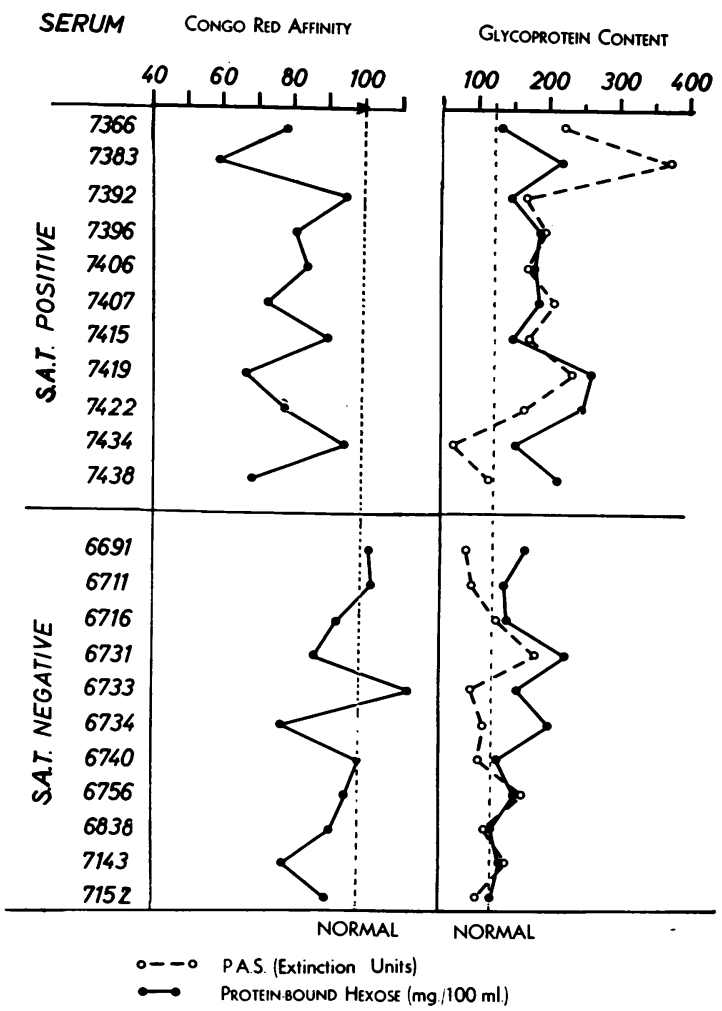

Fig. 1.-Correlation between congo red affinity and serum glycoprotein content in eleven cases with S.A.T. negative sera and eleven cases with S.A.T. positive sera. 
100 per cent., i.e. where they are tending towards the normal, the total of protein-bound hexose also tends towards the normal, $123 \mathrm{mg} . / 100 \mathrm{ml}$. serum (Larsen, 1958), and the P.A.S. intensity shows the same fluctuations.

Determinations of congo red affinity were also carried out on sera from four patients with systemic lupus erythematosus, one with proven amyloidosis, and on nine sera from patients with diabetic nephropathy. Table II shows the decreased congo red affinities and the increased serum glycoprotein concentrations in these sera.

TABLE II

CONGO RED AFFINITY FOR SERUM AND SERUM CONTENT OF GLYCOPROTEIN IN OTHER SERA

\begin{tabular}{cccc}
\hline Diagnosis & $\begin{array}{c}\text { Subject } \\
\text { No. }\end{array}$ & $\begin{array}{c}\text { Congo Red } \\
\text { Affinity } \\
\text { (per cent.) }\end{array}$ & $\begin{array}{c}\text { Protein-Bound } \\
\text { Hexose } \\
\text { (mg. per cent.) }\end{array}$ \\
\hline Systemic Lupus & II & 92 & 131 \\
Erythematosus & III & 55 & 156 \\
IV & 85 & 165 \\
Amyloidosis & Afd. B. & 31 & 139 \\
\hline-1 & OL. & 69 & 196 \\
\hline KT. & 75 & 191 \\
Diabetic & 294 & 65 & 185 \\
Nephropathy & 296 & 41 & 164 \\
& 296 & 42 & 235 \\
& 297 & 83 & 213 \\
& 298 & 70 & 257 \\
& 303 & 78 & 137 \\
& 304 & 66 & 192 \\
\hline
\end{tabular}

The result of dividing the sera into groups with increasing congo red affinity and determining the average glycoprotein content in these groups is demonstrated in Fig. 2 on the S.A.T. sera and in Fig. 3 (opposite) on sera from patients with proven rheumatoid arthritis. These Figures show an inverse ratio between congo red affinity and the serum content of glycoproteins.

The serum albumin concentration is plotted against the congo red affinity in Fig. 4 (opposite). Here some correlation is demonstrated between the albumin content and the degree of congo red uptake in the serum, but fluctuations in the congo red affinities are greater than the albumin variations.

\section{Discussion}

The comparability of the congo red method in vitro with the original Bennhold method in vivo is favourable as regards the degree of dye retention in the serum. As shown by Sairanen, Koskinen, and Holopainen (1955), normal subjects exhibit a disappearance of congo red of 33 per cent. and patients with rheumatoid arthritis of 48 per cent. The congo red affinity was lowered by 15 per cent. for patients with rheumatoid arthritis, and by the in vitro method this difference was of the same order of magnitude.

Among soluble proteins serum albumin is outstanding in forming reversible complexes with as variety of compounds of known structure, in pars ticular with organic anions (Klotz and Urquhartio 1949). It was therefore thought that the low? albumin content seen in the sera investigated could account for the lowered affinity of serum for congo red (Rawson, 1943). The variations in albumin concentrations showed a correlation with the congo

CONGO RED AFFINITY (per cent.)

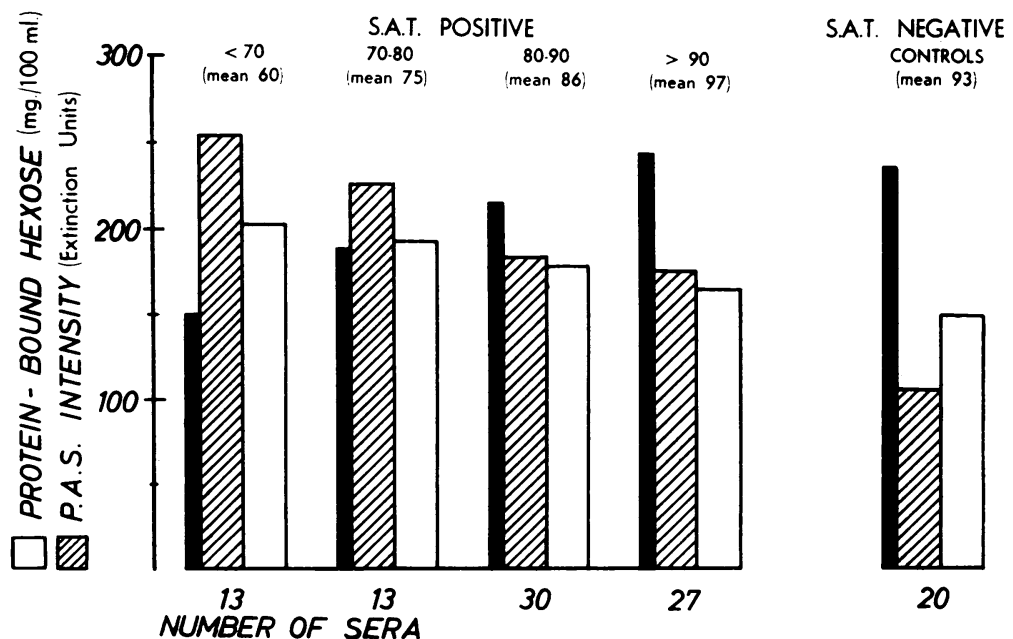

Fig. 2.-Classification of 83 S.A.T. positive sera into four groups of increasing affinity to congo red. showing high serum glycoprotein content in the groups with low congo red affinity and vice versa. The control group is composed of twenty $\mathrm{S}$. A.T. negative sera. 


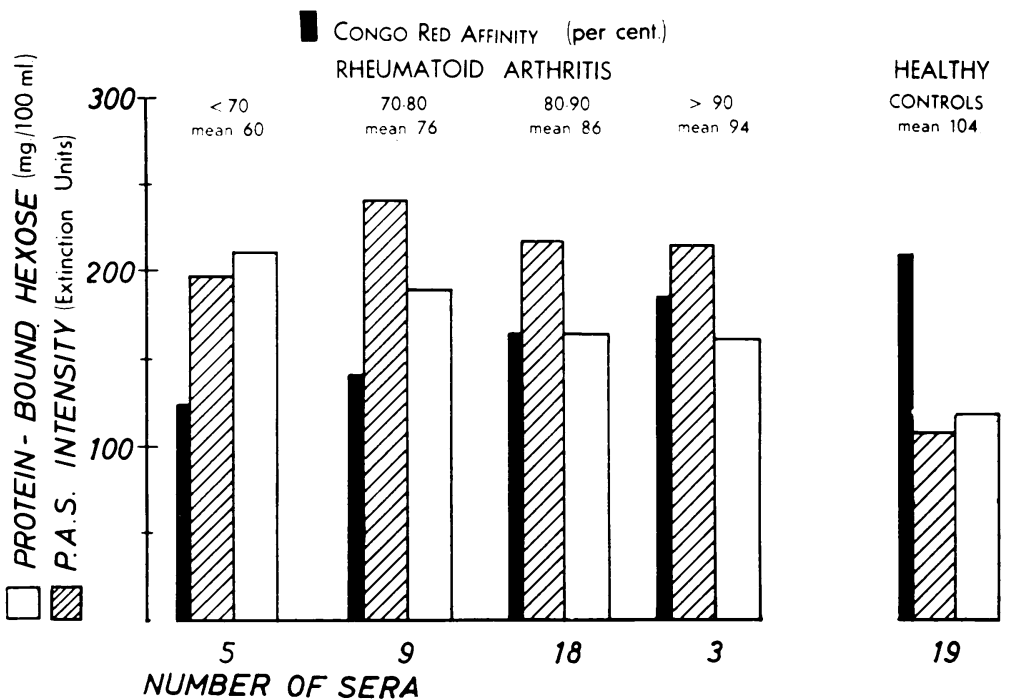

Fig. 3.-Clawitication of 35 sera from patients with rheumatoid arthritis into four groups of increasing affinity to congo red a 1 Fig. 2 . The control group comprises nineteen sera from healthy subjects.

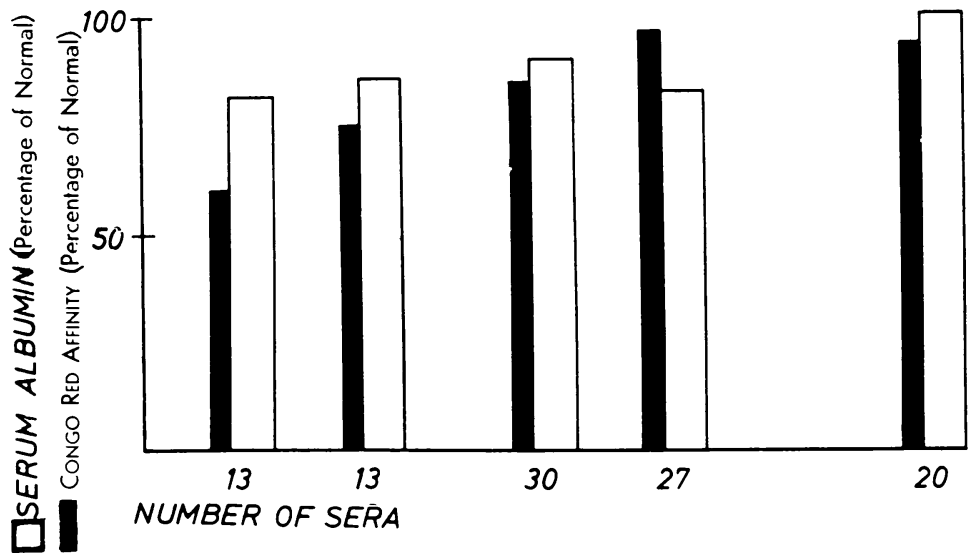

Fig. 4. - Comparion of congo red affinity for serum and serum albumin in groups of increasing congo red affinity. for 83 S.A.T positive sera and twenty S.A.T. negative sera.

red affinity. While the role of albumin in the binding of congo red cannot be excluded, other factors may also be operative. Organic ions are known to compete with different dye anions in their affinity for serum albumin: for instance, anionic dyes can compete with polysaccharide anions (Klotz. 1953). The same competitive effect may be demonstrated by the in vitro distribution method using congo red (Larsen, 1958).

It is therefore probable that the high content of glycoproteins in the serum may suppress the congo red affinity for the serum just as an increased glyco- protein concentration may reflect an increased concentration of polysaccharide anions.

\section{Summary}

A new method of determining the congo red affinity of serum has been devised, whereby the distribution of congo red between cellulose powder and serum is estimated.

The congo red affinity of sera from patients with rheumatoid arthritis, lupus erythematosus, diabetic nephropathy, and amyloidosis, was decreased. The serum glycoprotein content of the same sera was 
increased and the ratio between congo red affinity and serum glycoprotein content varied inversely.

It is suggested that the decreased congo red affinity for the sera investigated may be due not only to the lowered serum albumin content but also to the competition of congo red with polysaccharide anions.

The author wishes to thank Dr. K. Kalbak who gave him the impetus to start these studies.

\section{REFERENCES}

Aegerter, E., and Long, J. H. (1949). Amer. J. med. Sci., 218, 324 Bennhold, H. (1923). Dtsch. Arch. klin. Med., 143, 32

Björnesjö, K. B. (1955). Scand. J. Clin. Lab. Invest., 7, 147.

Dixon, A. St. J., Ramcharan, S., and Ropes, M. W. (1955). Ann. rheum. Dis., 14, 51 .

Johansson, G. A., and Pfeiffer, H. H. (1954). Acta Anat., 20, 285.

Klotz, I. M. (1953). "The Proteins", ed. H. Neurath and K. Bailey, vol. 1, p. 801. Academic Press, New York.

- and Urquhart, J. M. (1949). J. Amer. chem. Soc., 71, 1597.

Larsen, B. (1958). Scand. J. clin. Lab. Invest., 10, 210.

Laurell, C. B., and Skoog, N. (1956). Ibid., 8, 21.

Rawson, R. A. (1943). Amer. J. Physiol., 138, 708.

Sairanen, E., Koskinen, H. M., and Holopainen, T. (1955). Acta rheum. scand., 1, 262.

Stemmerman, M. G., and Auerbach, O. (1944). Amer. J. med. Sci., 208, 305 .

Taran, A., and Eckstein, A. (1942). Ibid., 203, 246.

Waddell, W. J. (1956). J. I ab. clin. Med., 48, 311.

Relation entre l'affinité pour le rouge Congo et le contenu du sérum en glycoprotéines dans l'arthrite rhumatismale et les maladies apparentées

RÉSUMÉ

On a imaginé un nouveau procédé pour determiner l'affinité pour le rouge Congo en mesurant sa distribution entre une poudre de cellulose et le sérum.

L'affinité pour le rouge Congo des sérums des malades atteints d'arthrite rhumatismale, de lupus érythémateux, de nephropathie diabétique et de dégénérescence amyloïde était diminuée. Dans les mêmes sérums le taux des glycoprotéines se trouvait augmenté, en raison inverse de l'affinité pour le rouge Congo.

On suggère que l'affinité diminuée pour le rouge Congo des sérums étudiés serait due non seulement à un taux d'albumine sérique diminué, mais aussi à la concurrence entre le rouge Congo et les anions polysaccharides.

Relación entre la afinidad para el rojo congo y el contenido de las glicoproteinas en el suero en la artritis reumatoide $y$ las enfermedades afines

\section{SUMARIO}

Se inventó un nuevo método para determinar la afinidad para el rojo congo; este consiste en medir su distribución entre un polvo de celulosa y el suero.

La afinidad para el rojo congo de los sueros de enfermos con artritis reumatoide, lupus eritematoso, nefropatia diabética y amiloidosis se vió disminuida. En los mismos sueros la glicoproteinas se vieron aumentadas en razón inversa de la afinidad para el congo rojo.

Se sugiere que la afinidad disminuida para el rojo congo de los sueros estudiados se debe no sólo a una baja de la albumina sérica, sino también a la rivalidad entre el rojo congo y los aniones polisacaridos. 